Eur. J. Clin. Chem. Clin. Biochem.

Vol. 30, 1992, pp. 387-390

(C) 1992 Walter de Gruyter \& Co. Berlin · New York

\title{
Isoelectric Focussing of Human Thyroxine Binding Globulin (Thyropexin) and Human Prealbumin (Transthyretin)
}

\author{
By Christine Luckenbach ${ }^{1}, R$. Wahl ${ }^{2}$ and E. Kallee ${ }^{2}$ \\ ${ }^{1}$ Institut für Anthropologie und Humangenetik \\ ${ }^{2}$ Medizinische Klinik und Poliklinik, Abteilung IV \\ Eberhard-Karls-Universität Tübingen
}

(Received November 7, 1991/April 22, 1992)

\begin{abstract}
Summary: Two batches of the highly purified thyroid hormone-binding plasma proteins, human thyropexin and transthyretin, which were prepared in gram quantities for use in animal experiments, were subjected to analysis by isoelectric focussing. Under these conditions, it was observed that human transthyretin was composed of two components. This was presumably due to the use of $8 \mathrm{~mol} / 1 \mathrm{urea}$. The preparations of both human transthyretin and human thyropexin contained some products of decomposition which probably arose in the course of the purification processes and, in addition, possibly also contained some normal genetic variants of human thyropexin. In spite of the alterations, both protein preparations largely retained their thyroid hormone-binding capacity, which is essential for in vivo studies on the re-entry of thyroid hormones from the extravascular space into the circulation. For therapeutic use in thyrotoxicosis, human transthyretin seems to be preferable to human thyropexin.
\end{abstract}

\section{Introduction}

The main thyroid hormone-binding plasma proteins in humans are thyropexin (1) ("TGB", human thyroxine binding inter-alpha globulin (2) $\left.)^{1}\right)$ and transthyretin (human thyroxine binding prealbumin) (3). Intravenously injected preparations of either human thyropexin or human transthyretin induced a rapid re-entry of large amounts of both radioactive and non-labeled triiodothyronine $\left(\mathrm{T}_{3}\right)$ and thyroxine $\left(\mathrm{T}_{4}\right)$ from the extravascular space into the circulation in experiments in rabbits $(4,5)$. The physiological principle of passive transport of thyroid hormones, mediated by thyropexin and transthyretin, might be exploitable as a novel approach to the treatment of

\footnotetext{
1) No reasonable word combinations for medical terminology can be formed with the acronym "TBG", e. g., "a-TBGaemia", "hypo-TBG-aemia", "dys-TBG-aemia" or "hyperTBG-aemia". It was therefore suggested that the generic name "thyropexin" be substituted for "TBG" and for "thyroxine binding inter-alpha globulin".
}

severe thyrotoxicosis in emergencies: The concentration of both $T_{4}$ and $T_{3}$ in the plasma can be significantly enhanced by i.v. injection of either human thyropexin or human transthyretin, thereby making $\mathrm{T}_{4}$ and $\mathrm{T}_{3}$ accessible to elimination by means of plasma exchange or plasmapheresis. In our previous experiments, however, the $\mathrm{T}_{4}$-binding ability of the human thyropexin preparation appeared to be slightly reduced (4). The integrity of the human thyropexin and human transthyretin preparations employed was therefore investigated by means of isoelectric focussing experiments.

\section{Materials and Methods}

\section{Proteins}

Since neither human thyropexin nor human transthyretin were commercially available in large quantities, specially purified human thyropexin and human transthyretin preparations were made by the Behringwerke (Marburg/L., Germany) specifically for the animal experiments described in a previous paper (4). 


\section{Isoelectric focussing}

For the isoelectric focussing $(6,7)$ experiments, polyacrylamide gels (Pharmacia-LKB, Freiburg, Germany) containing $8 \mathrm{~mol} / 1$ urea were employed. Carrier ampholytes (Pharmacia-LKB, Freiburg) were:

for human thyropexin:

$0.2 \mathrm{ml} \mathrm{pH} 3.5-10.0 ; 0.2 \mathrm{ml} \mathrm{pH} \mathrm{3.5-5.0;}$

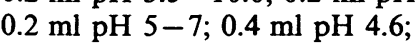

for human transthyretin:

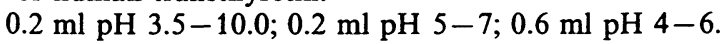

Focussing procedure: Macrodrive ${ }^{\circledR}-5$ power supply, Multiphore ${ }^{\circledR}$ electro-focussing unit (LKB, Freiburg, Germany).

Running conditions: $8{ }^{\circ} \mathrm{C}, 1500 \mathrm{~V}, 15 \mathrm{~mA}$; prefocussing in 2Watt steps, $10 \mathrm{~min}$ each until 10 Watts were reached; total IEF time $3-4.5 \mathrm{~h}$. Anolyte, $1 \mathrm{~mol} / \mathrm{l} \quad \mathrm{H}_{3} \mathrm{PO}_{4}$; catholyte, $1 \mathrm{~mol} / \mathrm{l}$ $\mathrm{NaOH}$.

Either $8 \mu$ l undiluted human donor plasma (controls) or $8 \mu \mathrm{l}$ purified human thyropexin or human transthyretin (both from Behringwerke, Marburg/L., Germany, or from UCB Bioproducts, Braine-L'Alleud, Belgium) were placed on the gel with $5 \times 5 \mathrm{~mm}$ filter papers (Pharmacia-LKB, Freiburg, Germany), human thyropexin $1.5 \mathrm{~cm}$ from the cathode, human transthyretin $1.2 \mathrm{~cm}$ from the anode.

\section{Western-blotting and EIA}

The proteins were passively transferred from the gel to nitrocellulose membranes (NCM $0.45 \mu \mathrm{m}$, Schleicher \& Schüll, Einbeck, Germany) by contact diffusion for $1 \mathrm{~h}$; washing steps were performed in phosphate-buffered saline solution containing $500 \mathrm{mg} / \mathrm{l}$ Tween $20^{\oplus}$ (Merck, Darmstadt, Germany); membranes were blocked with $50 \mathrm{~g} / 1$ bovine serum albumin (SIGMA, Deisenhofen b. München, Germany) in phosphatebuffered saline solution $\mathrm{pH}$ 7.4. First antibodies were goat antihuman thyropexin (Merz \& Dade) $1: 200$ in a phosphatebuffered saline solution containing $10 \mathrm{~g} / \mathrm{l}$ bovine serum albumin. Rabbit anti-goat immunoglobulin with conjugated peroxidase (Merz \& Dade) served as second antibody. This was diluted $1: 200$ with a solution containing $10 \mathrm{~g} / 1$ bovine serum albumin. First and second antibodies were reacted $1 \mathrm{~h}$ each successively; visualization was by $o$-toluidine-dependent peroxidase reactions.

\section{Results}

As shown in figure 1a, the thyropexin preparation from UCB Bioproducts (middle plate, track No. 1) reacted only faintly with the homologous antibody, although this human thyropexin was applied in a twoto threefold higher concentration than the other preparation (Nos. 2 and 3). The human thyropexin preparation in tracks 2 and 3 exhibited heavy trailing, probably due to partial polymerization in the course of purification. Neither the human thyropexin from UCB Bioproducts nor the human thyropexin from the Behringwerke was contaminated by the vitamin $\mathrm{D}_{3}$-binding group-specific components $\mathrm{Gc} 2-1 \mathrm{~F}$ or Gc $1 \mathrm{~F}$ (tracks 3 and 4 of left-hand plate). Moreover, no antigen-antibody reaction was observed with the $\alpha_{1}$-proteinase inhibitor in tracks 3 and 4 of the righthand plate.
As shown in figure $1 \mathrm{~b}$, the two main bands of the purified transthyretin preparation from Behringwerke (2nd plate from left, track No. 1) were corresponded to the two-banded pattern of native human transthyretin (track Nos. 2-4). The purified human transthyretin, however, contained numerous additional fractions not representing cross-reacting group-specific components Gc, retinol binding protein, or $\alpha_{1}$-proteinase inhibitor (track No. 2 in plates 1, 3 and 4 from left). The retinol binding protein has apparently been lost in the course of the purification process.

\section{Discussion}

In previous experiments (4), the thyroxine-binding capacity of the highly purified thyropexin preparation from Behringwerke was compared with the thyroxine binding capacity of the purified human thyropexin in the serum of an analbuminaemic subject. The thyroxine binding capacity of the purified human thyropexin was only $2 / 3$ to $3 / 4$ of the thyroxine binding capacity of native human thyropexin. As demonstrated in the present paper, this decrease of thyroxine binding capacity was probably due to unavoidable alterations of human thyropexin in the course of the purification process, giving rise to numerous degradation products. Similar effects apparently occurred with human transthyretin. These degradation products of human thyropexin or human transthyretin still reacted with either anti-human thyropexin or anti-human transthyretin antibodies exclusively. This was concluded from the fact that the anti-human thyropexin and anti-human transthyretin antibodies used showed no cross-reactions with serum proteins other than human thyropexin or human transthyretin, respectively. Thus, the degradation products of the purified human thyropexin and human transthyretin preparations displayed altered physico-chemical properties, but they were antigenically intact. Some of the supposed degradation products of human thyropexin may therefore also represent individual variants of normal human thyropexin $(8,9)$, especially since the human thyropexin was extracted from a pool of hundreds of donor blood plasma specimens.

In spite of the partial decomposition of the thyroid hormone-binding proteins, it could be shown in animal experiments that the re-entry of thyroid hormones from the extravascular space into the circulation is a purely passive process (5). As a consequence of this observation, very large doses of human thyropexin or human transthyretin might be used as a detoxicant for the treatment of severe thyrotoxicosis or thyroid storm, at least theoretically. The doses of human 

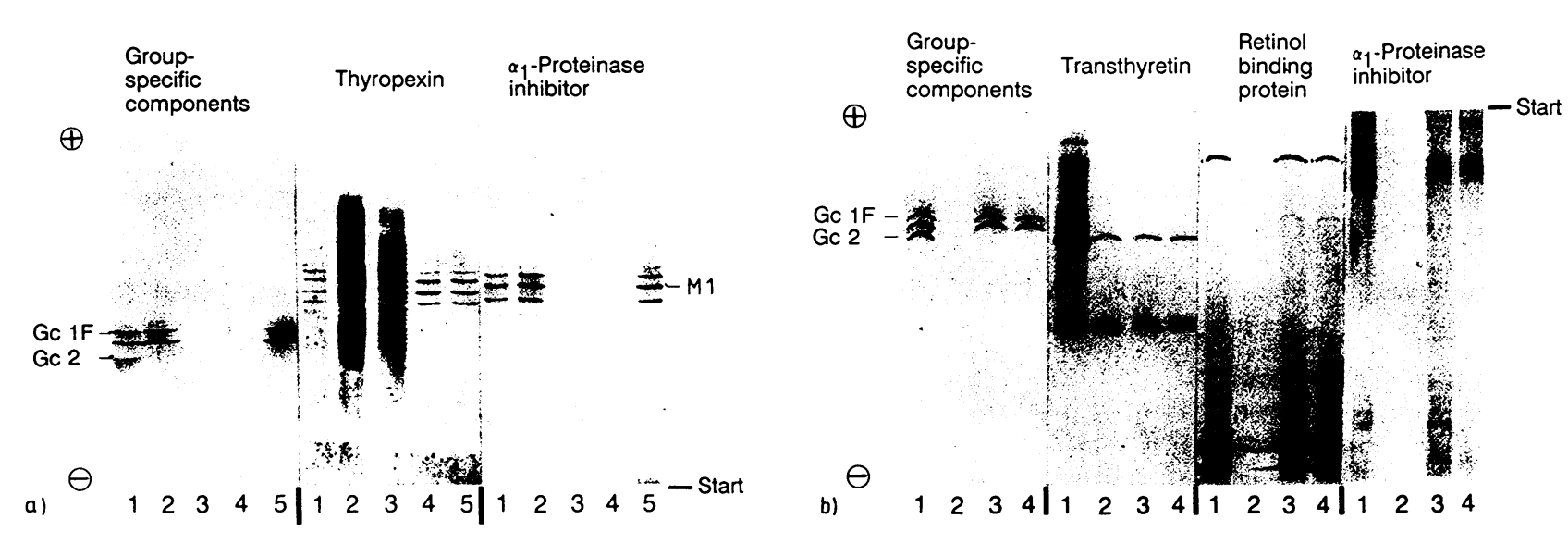

Fig. 1. Combined isoelectric focussing and immunological detection of purified thyropexin and transthyretin.

(a) Human thyropexin

Identification of tracks, from left to right:

Group-specific components $(\mathrm{Gc})$ :

(1) Gc 2-1F

(2) Gc 1F;

(3) human thyropexin from Bioproducts;

(4) human thyropexin from Behringwerke;

(5) Gc1F.

1st antibody: goat anti-Gc.

Thyropexin:

(1) human thyropexin from Bioproducts, $150 \mathrm{mg} / \mathrm{l}$;

(2) human thyropexin from Behringwerke, $75 \mathrm{mg} / \mathrm{l}$;

(3) human thyropexin from Behringwerke, $50 \mathrm{mg} / \mathrm{l}$;

(4 \& 5) native human thyropexin in human serum. 1st antibody: goat anti-thyropexin.

$\alpha_{1}$-Proteinase inhibitor:

(1 \& 2) $\alpha_{1}$-proteinase inhibitor $M 1$;

(3) human thyropexin from Bioproducts;

(4) human thyropexin from Behringwerke;

(5) $\alpha_{1}$-proteinase inhibitor M 1.

1st antibody: goat anti- $\alpha_{1}$-proteinase inhibitor $\mathrm{M} 1$ (b) Human transthyretin

Identification of tracks, from left to right:

Group-specific components (Gc):

(1) Gc 2-1F;

(2) human transthyretin from Behringwerke;

(3 \& 4) Gc1F.

1st antibody: goat anti-Gc.

Transthyretin:

(1) human transthyretin from Behringwerke;

$(2,3,4)$ native human transthyretin in human serum.

1st antibody: goat anti-human transthyretin Retinol binding protein:

(1) native retinol binding protein in human serum;

(2) human transthyretin from Behringwerke;

( $3 \& 4)$ native retinol binding protein in human serum.

1st antibody: goat anti-retinol binding protein $\alpha_{1}$-Proteinase inhibitor:

(1) $\alpha_{1}$-proteinase inhibitor $M 1$;

(2) human transthyretin from Behringwerke;

(3 \& 4) $\alpha_{1}$-proteinase inhibitor M 1 .

1st antibody: goat anti- $\alpha_{1}$-proteinase inhibitor $\mathrm{M} 1$.

All antibodies were from Merz \& Dade. thyropexin or human transthyretin necessary for just one single application, however, would correspond to the human thyropexin or human transthyretin content of approximately fifty to one hundred litres of human plasma.

Human serum albumin possesses a much higher $\mathrm{T}_{4}$ binding capacity than human thyropexin or human transthyretin, but a many times lower $\mathrm{T}_{4}$-binding affinity which, in the presence of human thyropexin and human transthyretin in vitro, amounts to only $5-10 \%$ of the total thyroxine binding capacity of whole serum or plasma. Consistent with this, human serum albumin was ineffective in our animal experiments (4).

At present, human thyropexin cannot be prepared for clinical use in humans, because it cannot be heat- sterilized. At temperatures of $\geq 56^{\circ} \mathrm{C}$, human thyropexin loses its thyroxine binding capacity. In addition, the human thyropexin fraction usually contains pyrogenic substances that cannot be removed by currently available purification processes. These considerations do not apply to human transthyretin, which therefore may be more suitable than human thyropexin as a new detoxicant for the emergency treatment of thyrotoxicosis.

\section{Acknowledgement}

The authors' thanks are due to Behringwerke A. G., Marburg/ L., in particular to Prof. Dr. Dr. h.c. H. G. Schwick, for providing special preparations of thyropexin and transthyretin. The linguistic advice of Dr. habil. G. Pawelec is gratefully acknowledged. 


\section{References}

1. Refetoff, S. (1989) Inherited thyroxine-binding globulin abnormalities in man. Endocrinol. Rev. 10, 275-293.

2. Kallee, E. \& Ott, H. (1992) Thyropexin(TBG)-Polymorphien, in "Innere Medizin in Praxis und Klinik" 4th edn. (Hornbostel, H., Kaufmann, W. \& Siegenthaler, W., eds.) pp. 17.116-17.119 Thieme, Stuttgart, New York.

3. Wojtczak, A., Luft, J. \& Cody, V. (1992) Mechanism of Molecular Recognition. Structural Aspects of 3,3'-DiiodoL-thyronine Binding to Human Serum Transthyretin. J. Biol. Chem. 267, 353-357.

4. Wahl, R., Schmidberger, H., Fessler, E., Heinzel, W., Schenzle, D., Bohner, J. \& Kallee, E. (1989) Effects of human thyroxine-binding globulin and prealbumin on the reverse flow of thyroid hormones from extravascular space into the blood stream in rabbits. Endocrinology 124, 1428-1437.

5. Kallee, E. \& Wahl, R. (1990) Passive transport of thyroid hormones from extravascular space into the circulation. Horm. Metabol. Res. 22, 128-129.
6. Svensson, H. (1961) Isoelectric fractionation and characterization of ampholytes in natural $\mathrm{pH}$-gradients. The differential equation of solute concentration at steady state and its solution for simple cases. Acta Chem. Scand. 15, 325341.

7. Luckenbach, C., Kömpf, J. \& Ritter, H. (1990) Genetic studies on human thyroxine-binding globulin (TBG). Hum. Genet. 84, 358-370.

8. Petek, W. (1979) Nachweis einer typenspezifischen Mikroheterogenität des humanen Thyroxin-bindenden Globulins durch isoelektrische Fokussierung. J. Clin. Chem. Clin. Biochem. 17, 105-110.

9. Almeida, M. R., Altland, K., Rauh, S., Gawinowicz, M. A., Moreira, P., Costa, P. P. \& Saraiva, M. J. (1991) Characterization of a basic transthyretin variant - TTR Arg 102 in the German population. Biochim. Biophys. Acta 1097, $224-226$.

Dr. rer. nat. Christine Luckenbach Institut für Anthropologie und Humangenetik Universität Tübingen

Wilhelmstraße 27

W-7400 Tübingen 1

Bundesrepublik Deutschland 